Pustelnika, Hilariona i Malchusa także żywoty wielu innych ojców i eremitów, jak o tym informuje podtytuł: Antiquorum Patrum vitas a beato Hieronymo conscriptas alphabetico ordine diligenter collectas, oraz Liber de obedientia, de humilitate et de sanctitate; dalsze trzy ostatnie patrystyczne inkunabuły seminaryjnej biblioteki w Tarnowie to najpierw Homiliarius doctorum a Paulo Diacono collectus, wydany 7 IX 1482 r. w Speyer przez Petrusa Dracha, naznaczony licznymi łacińskimi marginaliami kilku rąk z XVI wieku, dalej to zbiór mów św. Leona Wielkiego papieża († 460) - Sermones (nr 92), jeden z najcenniejszych, bo wydany ok. $1477 \mathrm{r}$. w jednej z najstarszych drukarni polskich działających w XV wieku w Chełmnie lub na Śląsku (Chetmno aut Silesia), przeznaczony zapewne dla kaznodziejów, i wreszcie jedna z pieśni wczesnochrześcijańskiego poety łacińskiego Wenancjusza Fortunata $(† 601)$ - De resurrectione Christi carmen ( $\mathrm{nr}$ 122, III 9, PL 88, 130-133), wydana ok. 1497 r. w Strasburgu przez Joannesa Grüningera razem z innymi średniowiecznymi pismami: Poenitentionarius de confessione i Hieronima de Vallibus - De passione Christi.

Ukazana wyżej szczegółowa tematyka patrystycznych inkunabułów, zgromadzonych $w$ tarnowskiej bibliotece seminaryjnej, informuje nas, które pisma Ojców Kościoła były przedmiotem lektury i studium ludzi (głównie ludzi Kościoła) południowej Polski. Wśród tych pism, zwłaszcza w inkunabułach Ambrożego i Augustyna, jest kilka nieautentycznych, ale za ambrozjańskie i augustyńskie w XV wieku uchodziły, i jako takie były czytywane. Należy się duża wdzięczność Autorce katalogu Dr Jolancie Marszalskiej również od patrologów za przybliżenie im inkunabułów tarnowskich, w tym także patrystycznych, świadczących, że myśl Ojców Kościoła była propagowana od samych początków stosowania sztuki drukarskiej, oraz życzyć jej dalszych sukcesów w odsłanianiu analogicznych skarbów podczas prac nad starodrukami nie tylko w Tarnowie, ale i planowanymi w Szczyrzycu i Wojniczu.

Ks. Stanisław Longosz - Lublin

\begin{abstract}
Mirosław DANILUK SCJ, Encyklopedia instytutów życia konsekrowanego i stowarzyszeń życia apostolskiego. Pojęcia - terminy instytucje - dokumenty - czasopisma, Lublin 2000, Redakcja Wydawnictw KUL, ss. 418.
\end{abstract}

W Redakcji Wydawnictw KUL ukazało się ostatnio drugie powiększone i uzupełnione bogatą bibliografią pod poszczególnymi hasłami wydanie opublikowanej po raz pierwszy w 1994 roku Podręcznej encyklopedii instytutów życia konsekrowanego (ss. 298) autorstwa M. Daniluka SCJ - K. Klauzy, tym razem pod nieco zmienionym, jak widać w nagłówku, tytułem i autorstwa już 
samego ks. M. Daniluka, znakomitego znawcy problematyki monastycznej i długoletniego pracownika Redakcji Encyklopedii Katolickiej KUL, w której jest kierownikiem działu „Zakony”. Warto tę pozycję tu odnotować, ponieważ zawiera ona wiele wzbogaconych najnowszą bibliografią haseł, które mogą zainteresować każdego patrologa, a zwłaszcza zajmującego się problematyką monastycyzmu starożytnego. Nie ma w niej żadnych haseł biograficznych, ale jak wskazuje podtytuł, dotyczą one przede wszystkim monastycznych pojęć, terminów, instytucji oraz dokumentów i czasopism ,związanych z kręgiem kultury Wschodu i Zachodu. Ukazanie jej bogactwa, różnorodności oraz ewolucji poszczególnych elementów jest zadaniem, jak informuje Autor, niniejszego opracowania encyklopedycznego" (s. 7). Hasła te, aczkolwiek o różnej tematyce monastycznej, ułożone w porządku alfabetycznym, z częstym wyjaśnieniem etymologii i dołączeniem nazwy łacińskiej oraz podaniem oboczności nazwy, powiązane zostały odsyłaczami łączącymi ze sobą poszczególne pojęcia, co pozwala uniknąć zbędnych powtórzeń. W porównaniu z pierwszym wydaniem encyklopedii, obecna opuszcza sigle zakonne, które Autor wydał wcześniej oddzielnie w poszerzonej formie (pt. Sigla. Zbiór skrótów nazw zakonów, zgromadzeń zakonnych, instytutów świeckich, stowarzyszeń życia apostolskiego oraz innych instytucji z nimi zwiazanych, Kraków 1999), gromadząc ich ponad 900. Na ostatnich 10 stronach omawianej Encyklopedii (s. 407-418) Autor dołącza 4 aneksy obrazujące wykresami strukturę i podział Instytutów Życia Konsekrowanego, Kongregacji Instytutów Życia Konsekrowanego i Stowarzyszeń Życia Apostolskiego, a także franciszkanów.

Spośród licznych haseł, które mogą zainteresować patrologa, są między innymi: Abba, Agapetki - synezakty, Anachoreci, Angelologia monastyczna, Apoftegmaty, Apokryzjariusz, Cela, Celibat, Cenobici, Czasopisma o tematyce monastycznej, Collationes Patrum, Demonologia monastyczna, Duchowość pustyni, Dziewice, Diakonisy, Erem - eremici, Esseńczycy, Filokalia, Hezychazm, Historia Lausiaca, Historia monachorum in Aegypto, Iroszkoccy mnisi, Kellia, Kellion, Klauzura, Konsekracja dziewic, Ławra, Monastycyzm (z bardzo bogatą bibliografią), Ojcowie pustyni, Pielgrzymowanie, Pustelnicy, Religiosus, Stupnicy - stylici, Sponsa Christi, Synaksis, Tau, Teologia monastyczna, Terapeuci, Tonsura, Wigilia, charakterystyka wszystkich starożytnych reguł zakonnych nazwanych od imienia ich twórcy (Augustyna reguła, Bazylego reguła, Benedykta reguła, Cezarego reguły, Fruktuoza reguła, Kolumbana reguta, Pachomiusza reguła).

Już wyżej wyliczone wybrane hasła wskazują, jest wielki jest ich tematyczny zakres i różnorodność. Autor nie sprecyzował jednak we wstępie, jakiego kryterium będzie się trzymał w doborze haseł, wskutek czego czytelnik nie wie do końca, co w tym bogactwie tematyki znajdzie, a czego mu zabraknie. Ponadto Autor wymieniając czasopisma o tematyce zakonnej, chyba się zagalopował i wymienił wśród nich również „Augustinianum”, które jest czasopi- 
smem ściśle patrystycznym, a nie monastycznym. Nie wiemy również dlaczego Autor wymienia tylko niektóre prowadzone przez zakony wyższe uczelnie kościelne, jak Anselmianum, Antonianum, Gregorianum, Marianum, Pontificia Università Salesiana, Pontificio Istituto di Studi Arabi e d'Islamistica (dlaczego tylko te?), a pomija prowadzony przez augustianów Instytut Patrystyczny „Augustinianum”, czy też prowadzone przez jezuitów Biblicum lub Ponticio Istituto Orientale. Jaki wreszcie bezpośredni związek z tematyką tej encyklopedii mają takie hasła, jak: Kustodia Ziemi Świętej, Misjologia, Martyrologium, Misjonarz apostolski, a brak w niej choćby takiego hasła jak Hagiografia monastyczna? Każdy autor dzieła dobiera sobie, oczywiście, tematykę, ale czy te właśnie hasła były w tej encyklopedii niezbędne? Wydaje się, że można by tych nieścisłości uniknąć, gdyby jaśniej było sprecyzowane kryterium doboru haseł. Wreszcie hasło Xenodochium odesłane do hasła hospicjum, niekoniecznie oznaczało w starożytności przyklasztorne pomieszczenie dla gości, ale w ogóle przydrożną oberżę lub szpital dla ubogich (zob. S. Longosz, Ksenodochium - hospicjum wczesnochrześcijańskie, VoxP 16: 1996, t. 30-31, 275-336). Tych kilka drobnych uwag, bynajmniej nie pomniejsza wartości tej wyjątkowo cennej, opracowanej z taką benedyktyńską sumiennością, i chyba jedynej nie tylko w Polsce, encyklopedii monastycznej, ale niech się one przyczynią do wzbudzenia jeszcze większego zainteresowania i zachęty, by może znalazła się ona na półce również patrologa.

Ks. Stanisław Longosz - Lublin

\section{SEDULIUS Caelius, Opera omnia - Dzieta wszystkie. Tekst laciń- sko-polski, przełożył, wstępem i komentarzem opatrzył ks. Henryk Wójtowicz, Lublin 1999, Wydawnictwo Towarzystwa Naukowego KUL, ss. 454.}

$\mathrm{Z}$ radością należy powitać opublikowane w Wydawnictwie Towarzystwa Naukowego KUL dwujęzyczne (łacińsko-polskie) tłumaczenie Dzieł wszystkich wczesnochrześcijańskiego poety łacińskiego, żyjącego w 1 poł. V wieku Seduliusza Celiusa. Piękna szata graficzna książki, dobry przekład dzieł, zwłaszcza poetyckich wierszem piętnastozgłoskowym, odpowiadającym umieszczonemu obok na stronie lacińskiemu heksametrowi, poprzedzony obszernym wieloaspektowym wprowadzeniem z obfitą bibliografią, budzi zainteresowanie i zachęca do lektury. To zainteresowanie i radość podzielają również nadsyłane do Tłumacza liczne gratulacje, jak np. ks. bpa radomskiego E. Materskiego: „Sedulius Caelius Opera omnia to świadectwo wielu lat żmudnej i wytrwałej pracy. Gratuluję i pragnę podzielać radość Księdza Profesora, bo tak piękny owoc pracy na pewno daje dużo radości”; czy też ks. bpa 